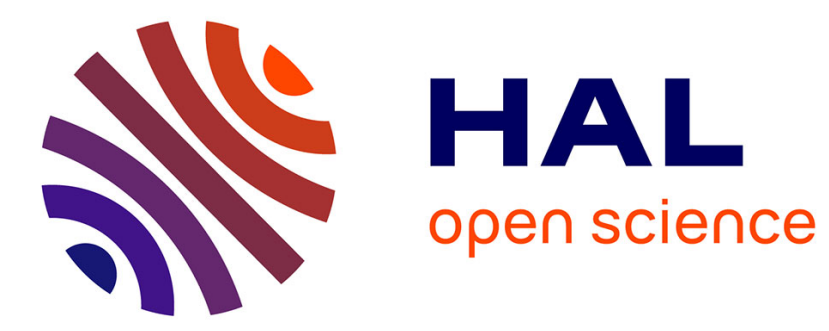

\title{
Irrigation canals as tools for climate change adaptation and fish biodiversity management in Southern France
}

Chantal Aspe, André Gilles, Marie Jacqué

\section{To cite this version:}

Chantal Aspe, André Gilles, Marie Jacqué. Irrigation canals as tools for climate change adaptation and fish biodiversity management in Southern France. Regional Environmental Change, 2016, 16 (7, SI), pp.1975-1984. 10.1007/s10113-014-0695-8 . hal-01444648

\author{
HAL Id: hal-01444648 \\ https://hal.science/hal-01444648
}

Submitted on 18 May 2018

HAL is a multi-disciplinary open access archive for the deposit and dissemination of scientific research documents, whether they are published or not. The documents may come from teaching and research institutions in France or abroad, or from public or private research centers.
L'archive ouverte pluridisciplinaire HAL, est destinée au dépôt et à la diffusion de documents scientifiques de niveau recherche, publiés ou non, émanant des établissements d'enseignement et de recherche français ou étrangers, des laboratoires publics ou privés. 


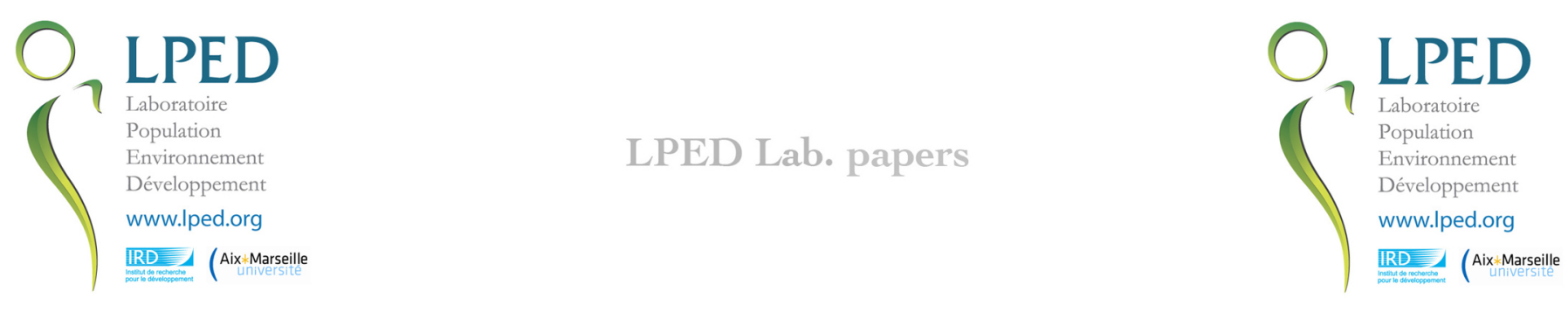

\title{
Irrigation canals as tools for climate change adaptation and fish biodiversity management in Southern France
}

\author{
Chantal Aspe · André Gilles · Marie Jacqué
}

Received: 9 May 2014/ Accepted: 13 September 2014

(C) Springer-Verlag Berlin Heidelberg 2014

\begin{abstract}
This paper is based on the interdisciplinary research conducted in the south of France that analyses the different economic, social and environmental roles played by agricultural irrigation canals. We argue that beyond their productive role, which is to supply farmers with water, they fulfil other environmental services and play an important role in the context of future climate change to face challenges of adaptation. We point up several ecosystem services provided by such canals, e.g. replenishing the groundwater table, the development of riparian vegetation and wet areas in the Mediterranean zone, tools for regulating flooding and drought, the bases for new cultural approaches to nature. Moreover, they play an important role in the maintenance of an ichthyological biodiversity that is indispensable for the persistence of natural ecosystem. Functioning as an ecological corridor, they display interesting capacities as refuges for certain fish species under stress. Indeed, they can potentially connect upstream and downstream zones over a continuum of more than $300 \mathrm{~km}$ and thus covering very contrasted climatic zones (alpine versus Mediterranean). For now, most of these services remain largely unknown and underestimated.
\end{abstract}

C. Aspe $\cdot$ M. Jacqué $(\square)$

IRD, LPED UMR D 151, Aix Marseille Université, 13331 Marseille, France

e-mail: marie.jacque@univ-amu.fr

C. Aspe

e-mail: chantal.aspe@univ-amu.fr

C. Aspe $\cdot$ A. Gilles

IMBE (UMR CNRS 7263, IRD 237) 'Evolution Génome

Environnement', CNRS, IRD, Avignon Université,

Aix-Marseille Université, 13397 Marseille, France

e-mail: andre.gilles@imbe.fr
However, they serve as assets for territorial development since they combine economic, ecological and social factors whose remodelling is becoming increasingly necessary in the face of climate change.

Keywords Irrigation canals - Ecosystem services · Climate change adaptation - Interdisciplinary research

\section{Introduction}

The numerous issues surrounding climate change have spurred a great deal of research worldwide that aims to renew thinking about water management (Milano et al. 2012; Garcia Ruíz et al. 2011). Most of this research advocates for water-saving measures and encourages the agricultural sector - the largest water consumer - to change its watering practices, notably by moving away from surface irrigation and instead developing overhead irrigation and drip irrigation techniques (Rodriguez Diaz et al. 2007; Iglesias et al. 2011a). In the south-east of France, agricultural irrigation canals, whose main productive role is to supply farmers with water, have indirect environmental effects that could be recognized as services: e.g. replenishing the water table, rainwater disposal and evacuation of torrential rains, landscape enhancement (Aspe et al. 2014) and the maintenance of biodiversity. These services remain largely unknown and are under-appreciated, but they could be major assets for the development of irrigated territories, particularly in the context of climate change. The very dense hydraulic network of irrigation canals that exists across the Provencal Territory means that such canals can play a role in adapting to the effects of climate change. To do so, it seems necessary to move beyond a quantitative approach to water management (Iglesias et al. 2011b; 
Arnell et al. 2011) and instead engage with thinking that examines the qualitative effects of its use.

In a first section, we shall begin by looking at how the indirect environmental effects of irrigation canals have gradually begun to be recognized thanks to the development of ecosystem services (Wolter 2010; Chester and Robson 2013). Their perpetuation is as such an important aspect of water resource sharing in the context of climate change. Over time, this approach may allow for better remuneration, via payments for environmental services, made to the facilities that manage them. Our current interdisciplinary research also aims to show that beyond their economic and social utility, irrigation canals are part of a complex hydro-social system that appears to play an important role in maintaining the ichthyological biodiversity of rivers (Katano et al. 2003; Rosenvald et al. 2014; Colvin et al. 2009). The second section will show how irrigation canals help maintain biodiversity at the scale of the Durance basin and how they could constitute tools for managing biodiversity to address future climatic trends. For them to be considered as such, changes are likely needed in how they are managed; they also need to be permanently integrated into territorial development policies.

\section{From productive water to environmental water: towards recognizing the ecosystem services of irrigation canals in the context of climate change}

In the south-east of France, agricultural irrigation canals are a key infrastructure for the sharing and management of water resources. The first canals were built in the Durance River basin between the Middle Ages (St Julien canal, 1171) and the Renaissance (Craponne canal, 1554) to channel water for its driving force. The Durance region's hydraulic infrastructure grew in the late eighteenth century and really flourished in the nineteenth century, with the construction of numerous structures and the development of a network of secondary canals and distributaries (small canals made of earth that supply and divide plots) for farming purposes. Their construction was the product of a combination of the economic interests of large farmers and the planning ambitions of the state which sought to increase the agricultural yield from the plains of Southern France to secure food supplies for cities. From the late nineteenth century onwards, the Durance canals allowed irrigated agriculture to develop, an intensification of production, an increase in crop area and the introduction of new crops. There are currently fifteen canals which contain 200 million cubic metres of the 1.2 billion stored in the Serre-Ponçon dam built in 1955. They distribute water across the entire Provencal Territory via a network of gravity-fed canals that represent $540 \mathrm{~km}$ of primary structures and 4,000 km of secondary networks, and cover a surface area of 150,000 hectares (Balland et al. 2003). Figure 1 shows the main canals of the lower Durance and the expanse of territories - the so-called irrigated areasthey supply (Fig. 2).

Since the law of 21 June 1865, irrigation canals have been managed by Authorized User Associations (ASAs); landowners automatically have member status in the associations for as long as they own their property. Each landowner whose property contains a section of canal is obliged to participate financially (i.e. via the payment of a fee) and technically (i.e. via a servitude) in running the hydraulic infrastructure. In exchange, the person has a right to use the resource based on conditions (e.g. rates, irrigation turn) set by the ASA. The entire surface area of irrigated land comprises the canal's perimeter and corresponds to the ASA's area of intervention. Until fairly recently, the management of irrigation canals occurred in a predominantly agricultural context and the upkeep of the hydraulic network of each perimeter (cleaning distributaries, clearing, etc.) was an integral part of each farm's work. While this remains the case in most areas supplied by the Durance canals, newer property owners are less and less likely to be farmers, but they continue to benefit from the rights associated with the canal's presence on their property; housing developments, golf courses and business parks are increasingly common and occupy land previously used for farming.

These new landowners are often much less assiduous about maintaining the secondary canal networks, when their distributaries are not simply covered over or filled into save space. Weakened by agricultural abandonment (changes in land use), urbanization and the decreasing number of farmers, the irrigators' associations are now seeking to accommodate new uses of the resource in order to preserve the hydraulic structures. Agreements have been signed, for example, with municipalities for the watering of municipal "green space" and with private sector actors from golf courses.

The use of water for farming purposes, which represents $70 \%$ of the resource's global consumption, is presented in international reports as the sector that needs to make the greatest water-saving efforts (FAO 2007; OECD 2013). It is as such that European and international policy support measures to modernize irrigation networks and reduce the use of surface irrigation techniques (EEA 2012) in favour of systems that consume less. While we do not wish to challenge the utility of overhead and drip irrigation, we feel that the maintenance of irrigation canals-which mobilize large volumes of water-could become essential for local societies to adapt to changes in climatic conditions. Indeed, the specific services provided by gravity-fed networks 


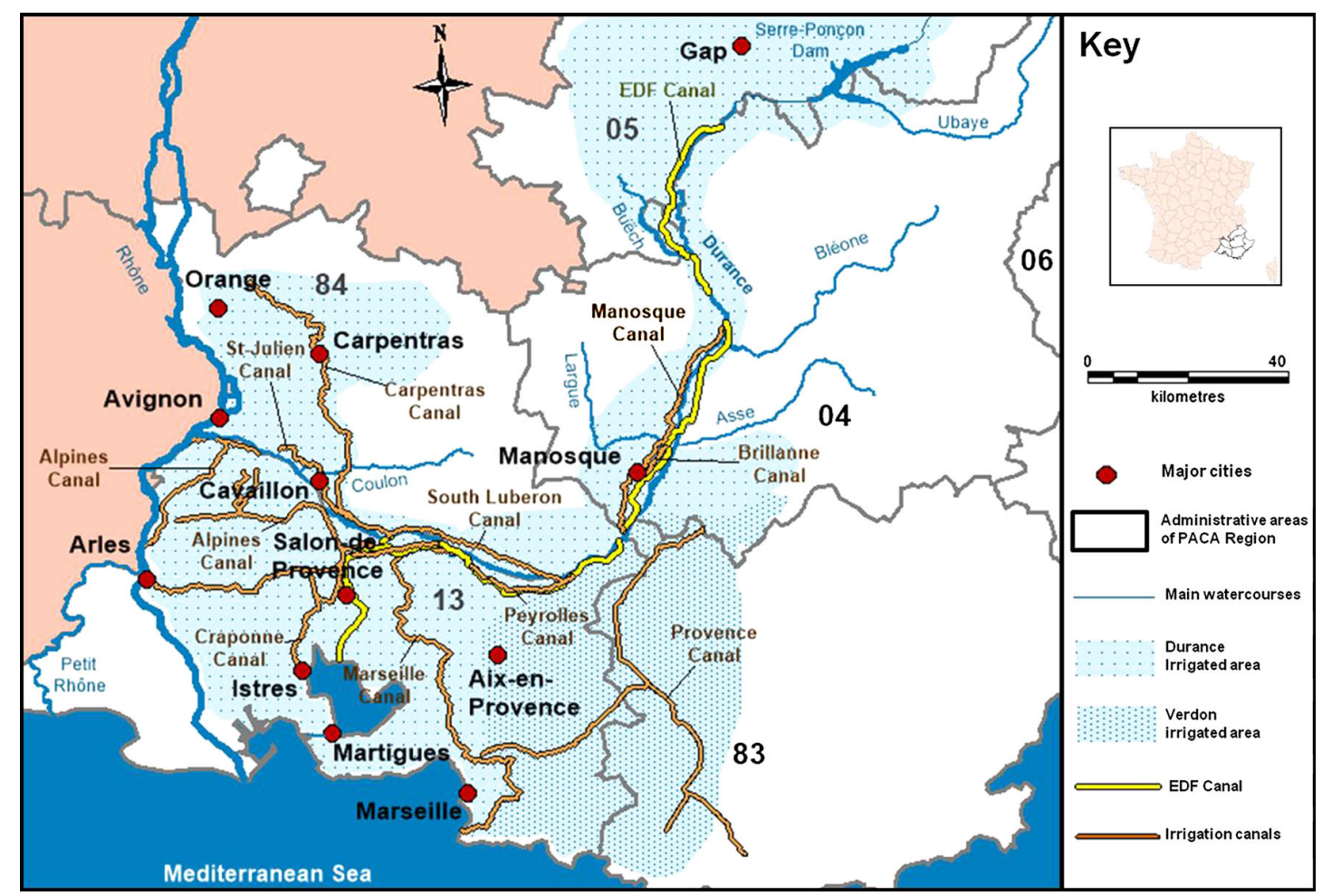

Fig. 1 Main agricultural irrigation canals and their irrigated areas in the Val de Durance (south-east of France)

Fig. 2 A view of Marseille canal (Bouches-du-Rhône, France)

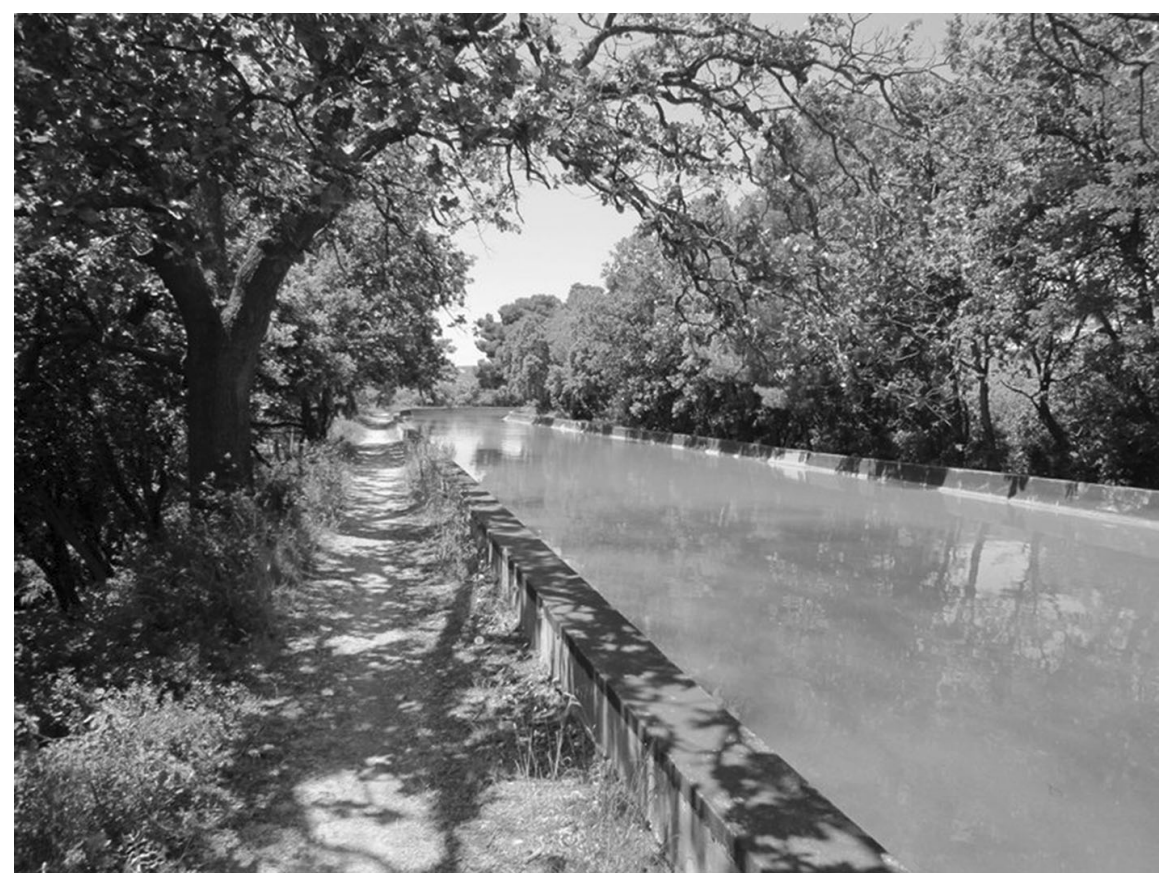

address two major challenges that Mediterranean societies will have to face: the scarcity of the resource and protection during increased periods of intense rainfall. The Mediterranean region will likely experience a rise in temperatures and an increase in droughts (GIEC 2007; Dequé 2007; Kuglitsch et al. 2010; Hertig et al. 2010; Hoerling et al. 2012) that will in turn likely affect the availability of water resources (Douville and Terray 2007; 
Braconnot et al. 2007; Lespinas et al. 2010; Milano et al. 2012). According to IPCC experts, the estimated water deficit for the Mediterranean basin varies between 45 and $60 \mathrm{~mm}$ per decade, with greater variability in precipitation and, especially, an intensification of rainfall episodes and extreme hydrological phenomena that will cause an increase in water levels, run-off water, flooding, etc. (GIEC 2007; Durand et al. 2009; Bigot and Rome 2010).

The water in irrigation canals represents a useable supply for the needs of irrigated Mediterranean agriculture, as well as for new urban and peri-urban uses in the zones they transect. Use of water from the canals as such limits the amount of water drawn from the water table; further, the hydraulic infrastructure they form is a structural tool for sharing the resource that exists and can continue to play an essential role in a context of heightened water stress. Given the way irrigation canals works, they also help renew groundwater resources. Indeed, the circulation of water through the entire network of distributaries and irrigation ensure that the region's main water tables are replenished. The most emblematic example is the $\mathrm{Crau}^{1}$ which is practically devoid of surface water but has a water table containing 550 million cubic metres that supplies 270,000 inhabitants with water in the Bouches-du-Rhône department and Fos industrial zone. Two-third of this aquifer's replenishment comes from irrigation water diverted from the Durance via the Craponne canal (CED 2007; Berard et al. 1995; Bourrie et al. 2012). At present, the perpetuation of this water table is "totally dependent on intake from leaks in canals and percolation from surface irrigation, estimated at 160 Mm3/year" (Balland et al. 2003) [translated here]. In the Durance sector, irrigation water also plays an important role in the maintenance of several groundwater resources. According to a study commissioned by the St Julien canal ASA in 1999, the water table of the lower Durance region is supplied for $75 \%$ with irrigation water versus only $25 \%$ by natural means (watercourses and precipitation) (Blavoux 2003). Recent research into the water table that supplies the city of Avignon further confirmed the importance of this proportion and the major role played by irrigation water in replenishing the aquifer (Nofal et al. 2012).

Irrigation canals are also water draining facilities. They as such supply another indirect service-rainwater disposal-and play a significant role in protecting against flooding during periods of intense rainfall. For example, in the Salon-de-Provence sector, irrigation canals drain off $35-100 \%$ of rainwater depending on the municipality (FDSH 13 2008). An economic evaluation of the canal's replacement cost was conducted by the city of Sisteron.

\footnotetext{
1 The Crau or the Crau plain is a paleo-delta of the Durance near the Camargue in the Bouches-du-Rhône department.
}

Were the Saint-Tropez canal hydraulic structure to disappear, the municipality would have to invest a million euros, in addition to the cost of maintaining a drainage system, whereas the annual maintenance cost of the main agricultural canal and its secondary network is estimated at 30,000 euros/year (Chambre d'Agriculture Alpes de Haute-Provence 2005). The Carpentras canal ASA has signed an agreement with the city of Carpentras for the regulation of rainwater. As a result, the municipality invested in the construction of a balancing tank to relieve the main canal when necessary. The modernization and maintenance of hydraulic networks by ASAs increasingly include such new services, although they are still for the most part funded by the ASAs; their main challenge resides in ensuring that the entire hydraulic network covered is in good working condition. Some ASAs have acquired remote operated valves that allow them to react more quickly during periods of intense rainfall. Others ensure that distributary networks no longer used for farming are up-kept to ensure rainwater disposal. In the event of an increase in extreme rainfall events, the hydraulic network of irrigation canals could as such become an efficient monitoring and evacuation tool to prevent flooding. The decree of 1 July 2004, which modified the status of ASAs and repealed the law of 21 June 1865 that had governed them up until then, broadened the role and scope of user associations to include "the creation and management of facilities that help in risk prevention, the management of natural resources, and the planning of watercourses, roadways and networks" [translated here] (Balsan et al. 2007). The recognition of these services is a sign that irrigation canals are no longer valued solely for their productive merit but also for their environmental value (Aspe 2012).

That is why it is particularly through new types of public involvement in the environment field that a new assessment and remuneration of these services may be envisaged. Since the recommendations of the 2005 Millennium Ecosystem Assessment, promoting ecosystem services is one important angle of contemporary environmental policy. These services are defined as "the favoured means to understand how certain ecosystems have a positive, often unknown, impact on economic activity and 'human wellbeing", [translated here] (MEA 2005). Such services are divided into four categories: provisioning (food, energy), regulating (water quantity and quality), supporting (soil creation) and cultural services. The report estimates that $60 \%$ of these services are in decline due to anthropic pressure on ecosystems (MEA 2005). It therefore appears that one of the current challenges in water management is limiting its agricultural use while maintaining the ecosystem services provided by irrigation practices. A recent report entitled Releasing the Pressure: Water Resource Efficiencies and Gains for Ecosystem Services by 
researchers from the Stockholm Environment Institute (SEI) for the UNEP invites decision-makers and resource managers to shift from thinking in terms of traditional water productivity per unit of agricultural yield to a broader understanding of the concept that would encompass ecosystem services. "This is a challenge, because all too often the benefits from ecosystem services are neither immediately recognized, nor easily valued... Recognizing these wider benefits generated by water in respect of, for example, nutrient flows, cooling, providing habitats, and other supporting and regulating ecosystem services is the aim of our work" (Keys et al. 2012). Among other things, the report proposes ecosystem management tools in order to identify the different types of benefits of ecosystem services in their local context. These different types of benefits, as we have underscored, are numerous when it comes to agricultural irrigation canals and focusing solely on saving water does not seem appropriate in the Mediterranean context.

The maintenance of hydraulic irrigation infrastructure is particularly contingent on recognition of the specificities of Mediterranean agriculture and the types of water resource management that have allowed it to develop; rather than seeing the water used as "lost", this allows it to be understood as working to produce ecosystem services. For now, the monetary assessment and remuneration of these services remain fairly uncharted territory. Certain ASAs have signed local agreements with municipalities, which in most cases involve the participation of municipal technical staff in the network's maintenance. The monetary assessment of services provided "unintentionally" by the canals-like replenishing the aquifer-requires an assessment of what the services cost the irrigation activity on the one hand, and a definition of who are the direct beneficiaries and their remuneration methods (taxes, public funding, etc.) on the other hand (Kuhfuss and Loubier 2013). Since the implementation of agro-environment measures into the Common Agricultural Policy in 1992, farmers have slowly begun to include "services provided" to the environment in their farming practices. While they were initially funded in the context of public grants, environment services now tend to be negotiated in the context of market regulations that require the definition of beneficiaries deprived of these services (Pagiola and Platais 2002; Ferraro and Simpson 2002; Van de Sand 2012). Moreover, the implementation of payments for ecosystem services (PES) requires the emergence of new intermediary actors who see an interest in the monetary exchange of services (e.g. municipalities, private companies) (Bonnal et al. 2012).

Can the remuneration of environment services by the indirect users of canals truly provide a long-term management solution for hydraulic infrastructure facilities?
How can such funding be guaranteed in contexts in which farming plays an increasingly small part in the management of these facilities, evermore dependent on new uses? For now, the financial support garnered by ASAs for these new services remains marginal and is predominantly government subsidized via the Agence de l'eau (water agency). At the scale of the Mediterranean basin, the water agency has taken a governance approach via canal contracts whose goal is to get new actors involved in the canals' management (e.g. municipalities, non-farming users, nature conservation associations, fishing federations and river unions) through the signing of a charter of goals to help define the medium and long-term actions needed to ensure the perpetuation of hydraulic networks (Jacqué 2012). These charters are not a legal obligation and are not legally binding for the new actors associated with the management of canals.

The long-term viability of the Durance region's hydraulic infrastructure is now contingent on recognition of the indirect services it provides and on the funding it can secure from the facilities that manage them. As we have seen, these services may be advantages in future to help local societies adapt to climate change, whether in terms of managing water shortages or its abundance. If they are not rethought in a local context, water-saving policies currently conducted in the name of strategies to adapt to climate change could have a certain number of unwitting effects on the availability of water resources, as well as on the ecological quality of aquatic and land environments, both of which are main priorities in contemporary environmental policies.

\section{Ecological assessment versus economic evaluation: canals as biodiversity-management tools for the integrated development of territories}

The biodiversity of aquatic ecosystems will likely be particularly affected by hydrological changes connected to climate change (The Convention on Biological Diversity held in Nagoya in October 2010) adopted a strategic plan for biological diversity - the "Aichi Targets"-which set 20 quantified targets for the conservation and restoration of biodiversity to "halt the loss of biodiversity in order to ensure that by 2020 ecosystems are resilient and continue to provide essential services, thereby securing the planet's variety of life, and contributing to human well-being and poverty eradication" (CDB 2010). In the field of aquatic environment management, controlling and limiting sampling is a key factor for the preservation of ichthyological biodiversity. "It is almost certain that disturbances to freshwater ecosystems, such as dams, reservoirs and diversions for irrigation and industry, will endanger or 
Fig. 3 Electric fishing in an irrigation canal (VaucluseFrance)

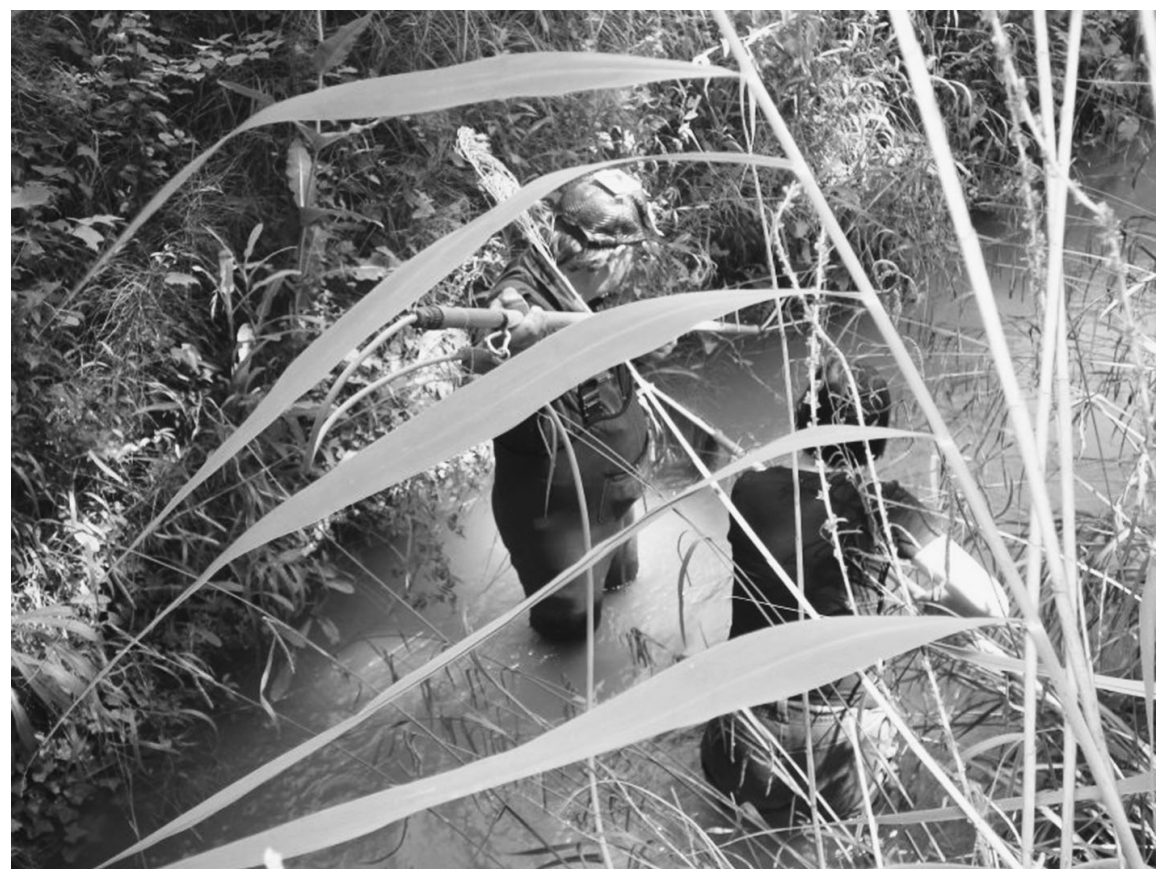

extinguish many freshwater fish species in future, by creating physical barriers to normal movements and migration of the biota and by decreasing habitat availability" (Leadley et al. 2010).

And yet, our initial findings on the ichthyological biodiversity of the Durance canals point up that the impact of these diversions on biodiversity is not necessarily negative. The hydrological network comprised of all of the main canals and their distributaries have produced an aquatic environment with ecological dynamics that are distinct from those in the regulated river but which are also complementary for the ichthyological population of the Durance. Indeed, the canals could not be considered as a "habitat analogous" (i.e. an environment that support indigenous biodiversity due to their structural or functional resemblance to natural ecosystem, Lundholm and Richardson 2010), because these artificial habitats displayed "a priori" none similar structures. The canals corresponded more to a functional novelty in which the different species could survive and spread through this aquatic network inducing a new area of biodiversity. Biodiversity here is measured by the abundance of fish and number of species, which is a particularly interesting indicator since fish species are central to the aquatic ecosystem (i.e. keystone species). Indeed, they play an important role in regulating the phytoplankton and zooplankton populations. As a result, fish are a bio-indicator of the state of the river as shown by the size of the populations present in an environment. The samples taken in irrigation canals (Fig. 3) show the presence of numerous fish species, proof of the broad ecological diversity, including of some protected species: vairone (Cyprinidae, Leuciscus souffia) and apron (Percidae, Zingel asper), the former of which is listed in Annex II of the Habitat-Fauna-Flora directive and Annex III of the Bern Convention and the latter of which is considered to be "in critical danger of extinction". Within the canals, we find a food web characteristic of the Durance region ranging from herbivore-diatomivorous cyprinid species like Chondrostoma (Parachondrostoma toxostoma and Chondrostoma nasus) to omnivores like chub (Squalius cephalus), spirlin (Alburnoides bipunctatus) and vairone, to insectivores like percid apron.

Our findings point up a close relationship between the hydraulic infrastructure of the canals and the circulation of fish upstream and downstream in the river. The canals play a role in maintaining freshwater fish biodiversity in the river via a return to the natural environment through tailwater and drainage water, as well as being a refuge zone for reproduction. One significant observation was that different species have even colonized infrastructure whose size does not exceed $50 \mathrm{~cm}$ in width and a water depth of $12-15 \mathrm{~cm}$. There is a large proportion young-of-the-year fish (20-30 mm TL) in these distributaries, which allows us to deduce that they are reproduction zones or capture zones stocking young specimens. We can as such assert that, during the impoundment period (which can last several years in the EDF power canal in which we also took samples), canals have great ichthyological diversity combined with a diverse population (i.e. individuals of varying age groups). 
Individuals present in the canals that are released in the Durance River during closure periods (or during a 10-year draining) may form an important source of diversity that allows for a restocking of the river, whose stocks can decline drastically after flooding (flow and clogging) or during the warmest periods (summer in France) inducing an increase in water temperature specially when heatwave occurs. However, it could be a pitfall for species living $<10$ years (as the highly protected $Z$. asper) especially if no reproduction was possible in the canal; thus, future studies will focus on this last point. Considering the other species, the canals are actually a receptacle of the Durance's diversity, which can be restored during canal draining operations, as well as throughout their impoundment via the return of tailwater and drainage water to the river. They can as such be seen as temporary refuges. And yet, is this the only role played by these commensals of the Durance River? Or rather, could these newly formed environments stocked by the Durance River not also be the source of a reconstructed biodiversity?

Moreover, the existence of genetic polymorphism in the Durance River for different species (specially for the "chondrostoma" species complex) can be explained by two complementary phenomena: a long-established local population (the populations belonging to the Rhone basin are more polymorphic than those belonging to the Garonne basin) and introgressive hybridization (a supply of new genic variants from the common nase ( $C$. nasus) compatible with the South-west European nase $P$. toxostoma) which increase genetic diversity both in individuals and the population (for more information, see Costedoat et al. 2004 for allozyme markers; Costedoat et al. 2007 for intron markers and Sinama et al. 2013 for microsatellite markers). However, molecular marker involved in the immune response as the major histocompatibility complex (MHC) presented a similar level of MHC polymorphism between both species and the hybrid specimens. Taking into account that the MHC plays an important role in pathogen and parasite resistance, it seems obvious that Durance environment selected specimens with "local" alleles (P. toxostoma). This is particularly true for the $C$. nasus specimens (the non-native species) that present pure genetic pedigree on neutral markers (based on 41 microsatellites), but adaptive alleles from $P$. toxostoma based on MHC.

These two phenomena (ancestral polymorphism and introgressive hybridization), which are at the corner stone of such strong genetic diversity, confer a new plasticity in the life history traits (Corse et al. 2009, 2012) of the endemic species, allowing it to survive in a modified environment.

The biodiversity generated by the hybridization phenomenon has, however, traditionally been underestimated either out of a lack of interest or due to a poor understanding of the phenomenon. Indeed, hybrids are often viewed as an aberration between two "pure" bloodlines rather than as an adaptive potentiality, an evolving novelty from which selection can occur and which could allow for the establishment of new lines (Crispo et al. 2011). We now know that $25 \%$ of embryophyte species (plants) are currently the product of hybrid lineages, as are $10 \%$ of animals (Mallet 2005). This research makes it clearly apparent that hybrids are an indicator of an ecosystem's biological diversity, living proof of the existence of unexploited or even new ecological niches (Seehaussen et al. 2008). Indeed, eutrophication can cause speciation reversal in whitefish (Salmonids fish) due to demographic decline and speciation reversal through introgressive hybridization (Vonlanthen et al. 2012). However, Nolte and Tautz (2010) have proposed an alternative model in which hybridization acts as a creative force, giving rise to novel traits imparting a new ecological potential absent from the parental lineages, which may be seen as a non-negligible source of adaptive variation in animals. It thus remains unclear whether these two outcomes (speciation reversal versus species formation) are mutually exclusive in a particular biological model (regardless of the environment) or whether the model responds differently in different environments (a mosaic of patterns).

The existence in the canals of individuals belonging to both "Chondrostoma" species and of a good number of hybrids allows us to assert that the canals have an impact on the evolutionary history of populations in the Durance River. Indeed, we found in Carpentras canal $17.39 \%$ of hybrid specimens, $20.29 \%$ of invasive species (C. nasus) and $62.32 \%$ of the endemic species ( $P$. toxostoma). Irrigation canals form a mosaic of pockets that contain the genetic resources of the Durance River and which can restock the river according to the variability of climatic conditions. The introduced common nase was meant to dominate and make the endemic South-west European nase disappear. As predicted by some author hybridization and introgression with non-indigenous species may lead to a form of extinction of endemic fish (Rhymer and Simberloff 1996). And yet this did not occur since both species coexist and are distinctly divided in the Durance ecosystem. The canals played a positive role in this context in the sense that they allowed for the maintenance of hybrid specimens (Aspe et al. 2014) and now function as reservoirs of biodiversity for the river, reservoirs whose evolution is governed by the genetic crossover they allow between the introduced species and the endemic species. In the context of climate change, these reservoirs could allow for the maintenance of genetic biodiversity and provide refuge conditions for these species. 
The preservation of hydraulic irrigation infrastructure is currently justified more for its environmental value than for its productive value, even if the latter remains an essential facet of its role. And yet, the economic evaluation of ecosystem services for maintaining biodiversity appears more complex and also raises a certain number of ethical issues. The Stern Review on the Economics of Climate Change (Stern 2006) was the first to calculate not the cost of environmental damage but rather the cost of inaction, advancing the idea that preventive measures are economically more profitable than those that seek to repair. Inspired by this approach, the UNEP created the Intergovernmental Platform on Biodiversity and Ecosystem Services (IPBES) to provide governments with a tool to evaluate the loss of biodiversity and the subsequent cost for national economies. In France, this evaluation was conducted by the Centre d'Analyse Stratégique (CAS), which published a report in 2009 (the "Rapport Chevassus") that provided an economic evaluation of the value of biodiversity at the national scale. The type of evaluation chosen was similar to the one used in the Millennium Assessment and adopted the same main categories of services. Although the authors specified several times that a monetary assessment was primarily meant to guide public decision-making for planning choices, ecosystems were nonetheless monetarily assessed and given a price that took into account their contribution to biodiversity (Chevassusau-Louis et al. 2009). The decision to attach a price meant that the assessment of the uses and territories managed was primarily market driven and used mainly economic tools rather than taking into account measures based on an ecological approach to conservation (Aubertin and Vandevelde 2009). The principle of economic compensation for the loss of biodiversity is the backbone of such marketdriven reasoning. A compensatory measure is an "ecological action that aims to restore or recreate a natural environment to offset the damage to biodiversity caused by a planning document or project. It addresses only the residual impact following prevention and impact mitigation measures, which are given priority" [translated here] (Commissariat Général au Développement Durable (CGDD) 2012). This approach was especially common in the so-called Grenelle 1 planning law of 2009, supplemented in $2010 .^{2}$ Compensatory measures are usually considered when avoidance measures have been examined but not chosen and when notable residual impact remains despite impact mitigation measures. It is what is expressed by the triptych: "avoid, reduce, compensate" (Ministère de

\footnotetext{
${ }^{2}$ Planning law n ${ }^{\circ} 2009-967$ of 3 August 2009 on the implementation of the Grenelle Environnement, JORF n ${ }^{\circ} 0179$, supplemented in 2010 by law n ${ }^{\circ} 2010-788$ of 12 July 2010 on the national commitment to the environment, completed on 1 January 2014.
}

l'écologie, du développement durable, des transports et du logement (MEDDTL) 2012). Too often, however, the "avoid" and "reduce" steps are skipped and focus is placed directly on the act of "compensating" and estimating how great the impact that needs to be compensated. The proposed compensatory measures are often devoid of any real stakes in terms of ecological functionality. The purchase of land in good ecological condition or putting land aside as a compensatory measure does not do any good for the environment, although that is the stated goal of compensatory measures. Ecosystems are not interchangeable and the disappearance of certain areas raises questions about the ecological functions that disappear with them.

The services provided by irrigation canals cannot be disconnected from the overall working of hydraulic infrastructure (at once ecological, economic and social) and their preservation cannot be bound up in a compensatory logic. Rather, the contemporary challenge resides in their perpetuation and avoiding even their partial disappearance. We believe that when these facilities are seen as planning tools for environmentally sustainable land, political and economic solutions may be envisaged. In France, municipalities need to play a greater role in their management, even if their involvement remains limited for now. Different regulations and policy approaches in the field of territorial planning should encourage this involvement. Municipalities are now asked to include all canals, even those that are only distributaries, in their urban planning documents and land use plans. ${ }^{3}$ Undertaken by a few municipalities in the Durance region, this approach is far from complete; one of the main challenges is to fully understand the entire hydraulic network that underpins each territory. The environmental value of irrigation canals as ecological corridors could also provide an argument for their perpetuation, and they could be included in new territorial planning tools such as green and blue corridors. ${ }^{4}$ Here too, it is up to municipalities, in agreement with government authorities, to draw up development plans that include green and blue corridors. The contemporary challenge will surely be to find a new economic balance and social compromise in the technical handling and management of these facilities.

Given the global environmental problem posed by climate change, we need to imagine practical and local solutions to adapt. The maintenance-and even the protection-of gravity-fed irrigation canals could be an efficient preventive measure to address the anticipated effects of warming in Mediterranean regions. While they may not

\footnotetext{
${ }^{3}$ Law on risks $n^{\circ} 2003-699$ of 30 July 2003 , Decree $n^{\circ} 2005-115$ of 7 February 2005 implementing articles L. 211-7 and L. 213-10 of the Code de l'environnement and article L. 151-37-1 of the Code rural. 4 Art. R. 371-16 of decree n²012-1492 of 27 December 2012.
} 
"save" water, these canals provide other environmental services that can play an important role in the balance of recognized advantages.

Acknowledgments Our research project HYODA ("Hydro-sociosystème-Durance-Acteurs"), Practices and social representations of environmental water. The Durance canals as the backdrop for new ecological, economic and social issues is financially supported by the Agence de l'Eau Rhône Méditerranée Corse and Electricité de France (EDF).

\section{References}

Arnell NW, van Vuuren DP, Isaac M (2011) The implications of climate policy for the impacts of climate change on global water resources. Glob Environ Change 21:592-603. doi:10.1016/j. gloenvcha.2011.01.015

Aspe C (2012) De l'eau agricole à l'eau environnementale. Résistance et adaptation aux nouveaux enjeux de partage de l'eau en Méditerranée. Quae Editions, Paris

Aspe C, Gilles A, Jacqué M (2014) The role of traditional irrigation canals in a long term environmental perspective-a case study in Southern France: the Durance basin. J Agric Sci Technol A $4: 1-12$

Aubertin C, Vandevelde JC (2009) Compte rendu de document. Approche économique de la biodiversité et des services liés aux écosystèmes. Nat Sci Soc 17:435-438

Balland P, Huet Ph, Lafont E, Leteurtrois JP, Pierron P (2003) Rapport sur la Durance. Propositions de simplification et de modernisation du dispositif d'intervention de l'Etat sur la gestion des eaux et du lit de la Durance. Contribution à un plan Durance. Ministère de l'Ecologie et du Développement Durable, Ministère de l'Agriculture, de l'Alimentation de la Pêche et des Affaires Rurales, Ministère de l'Equipement, des Transports, du Logement, du Tourisme et de la Mer, Ministère délégué à l'Industrie, Paris

Balsan S, Ferraud J, Piton N, Baury C (2007) Innovations sociales et Institutionnelles dans la Gestion de l'Irrigation en Méditerranée (ISIIMM). Document de synthèse, France: Etat des lieux des sites français (Durance, Têt). Euro-Mediterranean Regional Program for Local Water Management, Rapport ISIIM, Montpellier

Berard P, Daum J.R, Martin JC (1995) Actualisation du modèle de la nappe de la Crau. Rapport, BRGM R38199, Montpellier

Bigot S, Rome S (2010) Contraintes climatiques dans les Préalpes françaises: évolution récente et conséquences potentielles futures. EchoGéo 2010:14. http://echogeo.revues.org/12018

Blavoux B (2003) La réalimentation de l'aquifère alluvial par l'irrigation gravitaire en Basse Durance. Etudes Vauclusiennes 70:45-53

Bonnal Ph, Bonin M, Aznar O (2012) Les évolutions inversées de la multifonctionnalité de l'agriculture et des services environnementaux. VertigO 12(3)1-18. doi:10.4000/vertigo.12882 vertigo

Bourrie G, Trolard F, Jan A, Chanzy A, Lecerf R, Ruget F, Charron F (2012) Rôle de la composition de l'eau d'irrigation, des interactions avec les constituants des sols et de l'absorption de nutriments dans la protection de la qualité de la nappe de la Crau et des sols-un exemple ancien d'agriculture durable. Le sol face aux changements globaux, Actes du colloque, $11^{\text {ème }}$ journées d'étude des sols 70-74

Braconnot P, Dufresne JL, Salas y Mélia D, Terray L (2007) Analyse et modélisation du changement climatique, $2^{\text {eme }}$ édition du Livre blanc Escrime. Société Météorologique de France, Météo France
Chambre d'Agriculture Alpes de Haute-Provence (2005) Maintien et Sauvegarde du patrimoine hydraulique contribuant à la richesse environnementale. Rapport, Manosque

Chester ET, Robson BJ (2013) Anthropogenic refuges for freshwater biodiversity: their ecological characteristics and management. Biol Conserv 166:64-75. doi:10.1016/j.biocon.2013.06.016

Chevassus-au-Louis B, Salles JM, Pujol JL (2009) Approche économique de la biodiversité et des services liés aux écosystèmes. Contribution à la décision publique. Centre d'Analyse Stratégique, La Documentation Française, Paris

Colvin R, Giannico GR, Li J, Boyer KL, Gerth WJ (2009) Fish Use of Intermittent Watercourses Draining Agricultural Lands in the Upper Willamette River Valley, Oregon. Trans Am Fish Soc 138:1302-1313. doi:10.1577/T08-150.1

Commissariat Général au Développement Durable (CGDD) (2012) Compenser les atteintes à la biodiversité: expériences internationales et enseignements pour la France. Le point sur 133, Paris

Commission Exécutive de la Durance (CED) (2007) Une pratique et une expérience de plus de 100 ans de la gestion collective de l'eau et de la régulation concertée dans les territoires de basse Durance. Rapport, Aix-en-Provence

Convention sur la Diversité Biologique (CDB) (2010) Plan stratégique pour la diversité biologique 2011-2020 et les objectifs d'Aichi. PNUE

Corse E, Costedoat C, Pech N, Chappaz R, Grey J, Gilles A (2009) Trade-off between morphological convergence and opportunistic diet behavior in fish hybrid zone. Front Zool. doi:10.1186/17429994-6-26

Corse E, Neve G, Sinama M, Pech N, Costedoat C, Chappaz R, Gilles A (2012) Plasticity of ontogenetic trajectories in cyprinids: a source of evolutionary novelties. Biol J Linn Soc 106:342-355. doi:10.1111/j.1095-8312.2012.01873.x

Costedoat C, Salducci MD, Pech N, Chappaz R, Gilles A (2004) Etude de l'hybridation introgressive entre Chondrostoma t. toxostoma et Chondrostoma n. nasus (Téléostéen, Cyprinidae) en utilisant une approche multiple. Cybium 28(1suppl):51-61

Costedoat C, Pech N, Chappaz R, Gilles A (2007) Novelties in hybrid zones: crossroads between population genomic and ecological approaches. PLoS One 2:e357. doi:10.1371/journal.pone. 0000357

Crispo E, Moore JS, Lee-Yaw JA, Gray SM, Haller BC (2011) Broken barriers: human-indiced changes to gene flow and introgression in animals. BioEssays 33:508-518. doi:10.1002/ bies. 201000154

Dequé M (2007) Frequency of precipitation and temperature extremes over France in an anthropogenic scenario: model results and statistical correction according to observed values. Glob Planet Change 57:16-26

Douville H, Terray P (2007) Réponse du cycle hydrologique aux forçages anthropiques. La météorologie 57:31-36

Durand Y, Laternser M, Giraud G, Etchevers P, Lesaffre B, Mérindol L (2009) Reanalysis of 44 years of climate in the French Alps (1958-2002): methodology, model validation, climatology and trends for air temperature and precipitation. J Appl Meteorol Climatol 48:429-449. doi:10.1175/2008JAMC1808.1

European Environment Agency (EEA) (2012) Towards efficient use of water resources in Europe. EEA, Report 1, Copenhagen

FDSH 13 (2008) Pour une meilleure reconnaissance du rôle des ASA sur la Vallée de la Durance en Pays d'Aix. Fédération Départementale des Structures Hydrauliques des Bouches-duRhône, Aix-en-Provence

Ferraro PJ, Simpson RD (2002) The cost-effectiveness of conservation payments. Land Econ 78(3):339-353

Food and Agriculture Organization (FAO) (2007) The state of food and agriculture. Paying farmers for environmental services. United Nations Organization, Rome 
Garcia Ruiz JM, Lopez-Moreno JI, Vicente-Serrano SM, LasantaMartinez T, Begueria S (2011) Mediterranean wáter resources in a global change scenario. Earth Sci Rev 105:121-139. doi:10. 1016/j.earscirev.2011.01.006

Groupe d'Experts Intergouvernemental sur l'Evolution du Climat (GIEC) (2007) Bilan 2007 des changements climatiques, Contribution des groupes de travail I, II, III, au quatrième Rapport d'évaluation du Groupe d'experts Intergouvernemental sur l'Evolution du Climat, Genève

Hertig E, Seubert S, Jacobeit J (2010) Temperature extremes in the Mediterranean area: trends in the past and assessments for the future. Nat Hazards Earth Syst Sci 10:2039-2050. doi:10.5194/ nhess-10-2039-2010

Hoerling M, Eischeid J, Perlwitz J, Quan X, Zhang T, Pegion Ph (2012) On the increased frequency of Mediterranean drought. J Climate 25(6):2146-2161. doi:10.1175/JCLI-D-11-00296.1

Iglesias A, Mougou R, Moneo M, Quiroga S (2011a) Toward adaptation of agriculture to climate change in the Mediterranean. Reg Environ Change 11(suppl 1):S159-S166. doi:10.1007/ s10113-010-0187-4

Iglesias A, Garrote L, Diz A, Schlickenrieder J, Martin-Carrasco F (2011b) Re-thinking water policy priorities in the Mediterranean region in view of climate change. Environ Sci Policy 14:744-757. doi:10.1016/j.envsci.2011.02.007

Jacqué M (2012) Vers une nouvelle gouvernance des canaux, entre logiques territoriales et stratégies locales. In: Aspe C (ed) De l'eau agricole à l'eau environnementale. Résistance et adaptation aux nouveaux enjeux de partage de l'eau en Méditerranée. Quae Editions, Paris, pp 363-374

Katano O, Hosoya K, Iguchi K, Yamaguchi M, Aonum Y, Kitano S (2003) Species diversity and abundance of freshwater fishes in irrigation ditches around rice fields. Environ Biol Fishes 66:107-121. doi:10.1023/A:1023678401886

Keys P, Barron J, Lannerstad M (2012) Releasing the Pressure: Water Resource Efficiencies and Gains for Ecosystem Services. Nairobi: United Nations Environment Program; Stockholm: Stockholm Environment Institute (see Preface by Steiner A)

Kuglitsch FG, Toreti A, Xoplaki E, Della-Marta PM, Zerefos CS, Türkeş M, Luterbacher J (2010) Heat wave changes in the eastern Mediterranean since 1960. Geophysysical Research Letters 37(4):1-5. doi:10.1029/2009GL041841/full

Kuhfuss LS, Loubier S (2013) Comment évaluer les services rendus par les canaux d'irrigation? Application au cas de la recharge de nappe. Sci Eaux Territoires 11:70-75

Leadley P, Pereira HM, Alkemade R, Fernadez-Manjarreés JF, Provença V, Scharlemann JPW, Walpole MJ (2010) Scénarios de biodiversité : projections des changements de la biodiversité et des services écosystémiques pour le $21^{\text {ème }}$ siècle. Secrétariat de la Convention sur la Diversité Biologique, Montréal, Cahier technique $\mathrm{n}^{\circ} 50$

Lespinas F, Ludwig W, Heussner S (2010) Impact of recent climate change on the hydrology of coastal Mediterranean rivers in Southern France. Clim Change 99:425-456. doi:10.1007/ s10584-009-9668-1

Lundholm J, Richardson P (2010) Habitat analogous for reconciliation ecology in urban and industrial environments. J Appl Ecol 47:966-975. doi:10.111/j.1365-2664.2010.01857.x
Mallet J (2005) Hybridization as an invasion of the genome. Trends Ecol Evol 5:229-237

Milano M, Ruelland D, Fernadez S, Dezetter A, Fabre J, Servat E (2012) Facing climatic and anthropogenic changes in the Mediterranean basin : what will be the medium-term impact on water stress ? CR Geosciences 344:432-440. doi:10.1016/j. crte.2012.07.006

Millenium Ecosystem Assessment (MEA) (2005) Ecosystems and Human Well-Being. Synthesis. Island Press, Washington, DC

Ministère de l'écologie, du développement durable, des transports et du logement (MEDDTL) (2012) Doctrine relative à la séquence éviter, réduire et compenser les impacts sur le milieu naturel. MEDDTL Paris

Nofal S, Cognard-Plancq AL, Marc V, Tison F, Daniel M, Travi Y (2012) Impact de la gestion des eaux d'irrigation sur la recharge des nappes en Basse Provence. Exemple de la plaine d'Avignon. In: Aspe C (ed) De l'eau agricole à l'eau environnementale. Résistance et adaptation aux nouveaux enjeux de partage de l'eau en Méditerranée. Quae Editions, Paris, pp 159-173

Nolte AW, Tautz D (2010) Understanding the onset of hybrid speciation. Trends Genet 26:54-58. doi:10.1016/j.tig.2009.12.001

Organisation for Economic Co-opération and Development (OECD) (2013) Water and climate change adaptation. An OECD perspective. OECD, Paris

Pagiola S, Platais G (2002) Payments for Environmental Services Environment Strategy Notes 3. The World Bank, Washington

Rhymer JM, Simberloff D (1996) Extinction by hybridization and introgression. Annu Rev Ecol Syst 27:83-109. doi:10.1146/ annurev.ecolsys.27.1.83

Rodriguez Diaz JA, Weatherhead EK, Knox JW, Camacho E (2007) Climate change impacts on irrigation wáter requirements in the Guadalquivir river basin in Spain. Reg Environ Change 7:149-159. doi:10.1007/s10113-007-0035-3

Rosenvald R, Jaervekuelg R, Lhomus A (2014) Fish assemblages in forest drainage ditches: degraded small streams or novel habitats? Limnologica 46:37-44. doi:10.1016/j.limno.2013.12. 004

Seehaussen O, Takimoto G, Roy D, Jokela J (2008) Speciation reversal and biodiversity with hybridization in changing environments. Mol Ecol 17:30-44. doi:10.1111/j.1365-294X.2007. 03529.x

Sinama M, Gilles A, Costedoat C, Corse E, Olivier JM, Chappaz R, Pech N (2013) Non-homogeneous combination of two porous genomes induces complex body shape trajectories in cyprinid hybrids. Front Zool. doi:10.1186/1742-9994-10-22

Stern N (2006) Review on the economics of climate change. HM Treasury, UK

Van de Sand I (2012) Payments for ecosystem services in the context of adaptation to climate change. Ecol Soc 17(1):11. doi:10.5751/ ES-04561-170111

Vonlanthen P, Bittner D, Hudson AG, Young KA, Muller R, Lundsgaard-Hansen B (2012) Eutrophication causes speciation reversal in whitefish adaptive radiations. Nature 482:357-362. doi:10.1038/nature 10824

Wolter C (2010) Functional vs scenic restoration-challenges to improve fish and fisheries in urban waters. Fish Manage Ecol 17:176-185. doi:10.1111/j.1365-2400.2009.00725.x 